\title{
Physicochemical characteristics of substrates of the mixture of coir with municipal solid waste compost and with biochar
}

\author{
R.M.A. Machado ${ }^{1, a}$ and H.H. Bui² \\ 1MED - Mediterranean Institute for Agriculture, Environment and Development \& Departamento de Fitotecnia, \\ Escola de Ciências e Tecnologia, Universidade de Évora, Portugal; ${ }^{2}$ Department of Natural Sciences, Quy Nhon \\ University, Quy Nhon, Binh Dinh Province, Vietnam.
}

\begin{abstract}
The aim of this study was to evaluate the effect of mixing municipal solid waste compost and of biochar with coconut coir, in different ratios, on some chemical and physical properties of mixtures and its potential to grow plants. Coir was mixed with MWS and with biochar in the following ratios: 1:0, 3:1, 2:1, 1:1, 2:1 and 0:1 (v:v). The physicochemical characteristics measured were $\mathrm{pH}$, electrical conductivity, organic carbon, organic matter, mass wetness, moisture content and bulk density. The characteristics that raises more issues in the MSW compost were the high electrical conductivity (4.81 $\mathrm{dS} \mathrm{m}^{-1}$ ) and $\mathrm{pH}(8.21)$ and in the biochar was the high $\mathrm{pH}$ (9.11). The increase of coir in mix improved the chemical and physical characteristics and in either case, the most suitable mixture is the one with the ratio $3: 1$ (75\% coir by volume in the mixture). However, the electrical conductivity $\left(2.69 \mathrm{dS} \mathrm{m}^{-1}\right)$ of the mix 3:1 coir/MSW compost was still higher than the salinity threshold of the majority of the crops. The pH in coir/MSW compost and coir/biochar at the 3:1 ratio was 6.73 and 6.74 , respectively, slightly above the maximal value of adequate range (6.4). These findings indicate that the mix of coir with MSW compost and biochar increases the potential of those materials to be used as substrates to grow plants, but it is still necessary to do some adjustments.
\end{abstract}

Keywords: soilless cultivation systems, substrates, electrical conductivity, $\mathrm{pH}$

\section{INTRODUCTION}

Nowadays, in soilless culture in substrate, the main goal is to reduce the use of substrates with high negative environmental impacts as the peat (Gruda, 2019). The use of municipal solid waste compost and biochar, two organic waste materials in substrates may be a strategy since they are renewable resources, and they have a low carbon footprint due to transport. However, MSW and biochar have some physicochemical characteristics that may limit their use as stand-alone substrates. MSW compost usually has high salt concentrations and pH (Hargreaves et al., 2008), which can affect plant growth negatively. Biochar is a carbon-rich, solid residual product resulting from the pyrolysis (heating materials in the absence of oxygen) of various biomass feedstock's (Sohi et al., 2010) usually high in $\mathrm{pH}$, which can affect plant nutrition. The mixture of MSW and Biochar with coconut coir could be a way to surpass the limitations since the coir has low $\mathrm{pH}$ and low density, good physical stability and good air content and water - holding capacity (Michel, 2010, Gruda et al., 2016). Organic composts tend to have porosity and aeration properties comparable to those of peat (Fascella, 2015). Biochar could be suitable as replacements for peat in soilless substrates (Vaughn et al., 2013). Tomato plant heights and bell pepper (Capsicum annuum L.) dry weights increased with the addition of 1,3 and $5 \%(\mathrm{w} / \mathrm{w})$ to a soilless mixture of coconut fiber and tuff (volcanic ash) (Graber et al., 2010). The aim of this study was to evaluate the effect of mixture coir, with municipal solid waste compost and with

aE-mail: rmam@uevora.pt 
biochar on some chemical and physical properties of mixtures and to their potential to grow plants.

\section{MATERIALS AND METHODS}

The experiment was carried out at the Soil Physics Laboratory located at the Herdade Experimental da Mitra $\left(38^{\circ} 3152 \mathrm{~N} ; 8^{\circ} 0105 \mathrm{~W}\right)$, University of Évora, Portugal.

The experiment comprised three different substrates: coir (Projar S.A., Spain), municipal solid waste compost (Nutrimais, Lipor company, Portugal) and Acacia wood biochar (Ibero Massa, Oliveira de Azeméis, Portugal). The characteristics of the substrates, according to the manufacturer, are shown below. MSW compost in pellet form expressed as a percentage of compost dry weight had: organic matter $(52.47 \%), \mathrm{C} / \mathrm{N}$ ratio $(12.0), \mathrm{C}$ (29.15\%), $\mathrm{N}$ (2.41\%), $\mathrm{P}_{2} \mathrm{O}_{5}$ (1.49\%), $\mathrm{K}_{2} \mathrm{O}$ (1.81\%), $\mathrm{CaO}(15.17 \%), \mathrm{MgO}(0.7 \%)$, and 0.35, $32.00,22.33,49.00,0.1,7.47,160.00,38.00 \mathrm{mg} \mathrm{kg}^{-1}$ of $\mathrm{Cd}, \mathrm{Pb}, \mathrm{Cr}, \mathrm{Cu}, \mathrm{Hg}, \mathrm{Ni}, \mathrm{Zn}$ and $\mathrm{B}$, respectively. The electrical conductivity (EC) and $\mathrm{pH}(1: 2$ compost:water, V/V) were $5.4 \mathrm{dS}$ $\mathrm{m}^{-1}$ and 8.68, respectively. Acacia wood biochar from pyrolysis had a $\mathrm{pH}$ from 8 to 10, EC of $0.25 \mathrm{dS} \mathrm{m}^{-1}$, and granulometry $\geq 1$ and $<20 \mathrm{~mm}$.

The coir (cocopeat) had a pH of 5.5-6.0, EC $>1.5 \mathrm{dS} \mathrm{m}^{-1}$, granulometry $=0-10 \mathrm{~mm}$, total porosity $=95 \%$, air $(\%, v / v)=25$ and CEC $\left(\right.$ meq $\left.100 \mathrm{~g}^{-1}\right)=60-120$.

There were carried out two experiments, each with six the treatments, that consisted in six mixes of coir with MSWC and coir with biochar in the following ratios 1:0, 3:1, 2:1, 1:1, 2:1 and 0:1 (v:v). For each mix, five replicates were made.

The physicochemical characteristics of the mixtures measured were $\mathrm{pH}, \mathrm{EC}$, organic carbon, organic matter, mass wetness, moisture content and bulk density. The $\mathrm{pH}$ in $\mathrm{H}_{2} \mathrm{O}$ and the EC were measured in the aqueous extract (1:5 substrate:water, V:V). The aqueous extract of each mix was obtained by combining one part (by volume) of substrate with five parts (by volume) of distilled water. The sample was mixed and left to stand for $30 \mathrm{~min}$ to equilibrate. The mixture was poured into a clean funnel lined with a filter to avoid getting substrate in the solution. The $\mathrm{pH}$ and $\mathrm{EC}_{\mathrm{w}}$ (electrical conductivity in aqueous extract) were measured in the collected aqueous extract. The $\mathrm{pH}$ and $\mathrm{EC}$ were measured using a $\mathrm{pH}$ meter (Fiveeasy, Mettler Toledo) and a conductivity meter (LF 330 WTW, Weilhein, Germany), respectively.

Organic carbon (\%) was measured using a sulfur/carbon determinator (SC-144 DR, Leco Inc., USA). Organic matter (\%) was estimated from organic carbon (\%) using the conversion factor 1.72 [Organic matter $(\%)=$ total organic carbon $(\%) \times 1.72)$ ] (Pribyl, 2010). Physical properties of mass wetness, moisture content, and bulk density were determined following the methodology described by Fonteno and Harden (2003).

Data were processed by means of the variance analysis using SPSS Statistics 25 software (Chicago, Illinois, USA). Means were separated at the $5 \%$ level using Duncan's new multiple range test.

\section{RESULTS AND DISCUSSION}

The mixture of coir and MSW compost in different ratios affected significantly the physicochemical characteristics measured (Table 1). The $\mathrm{EC}_{\mathrm{w}}$ of the MSW compost in water MSW compost - water $(1: 5, \mathrm{v} / \mathrm{v})$ extract was high $\left(4.81 \mathrm{dS} \mathrm{m}^{-1}\right)$. This value was lower than the one mentioned by the producer $\left(5.4 \mathrm{dS} \mathrm{m}^{-1}\right)$, which can be due to the extraction ratio (1:2 substrate:water, $\mathrm{v} / \mathrm{v}$ ), but inside the range of the EC values, of the MSW composts mentioned to by Brady and Weil (1996) from 3.69 to $7.49 \mathrm{dS} \mathrm{m}^{-1}$. The increase of coir in the mixture decreased $\mathrm{EC}_{\mathrm{w}}$. However, the lowest value of $\mathrm{EC}_{\mathrm{w}}$ of the mixtures was $2.69 \mathrm{dS} \mathrm{m}^{-1}$, in mix 3:1. That $\mathrm{EC}_{\mathrm{w}}$ was still higher than the salinity threshold of the majority of the crops (Machado and Serralheiro, 2017, 2020).

The increase of coir in mixture decreased the $\mathrm{pH}$. The average $\mathrm{pH}$ of the mixtures with MSW compost ranged from 6.73 to 7.16 in mixture 3:1 and 1:2, respectively (Table1). Taking into account that the optimal substrate $\mathrm{pH}$ for most greenhouse and nursery crops is between 5.4 and 6.4 (Bailey et al., 2000) the pH of the mixture 3:1 is slightly above the desirable range.

The increase in coir in coir/MSW compost ratio decreases the bulk density, from 0.7 in 
the MSW to $0.33 \mathrm{~g} \mathrm{~cm}^{-3}$ in mixture 3:1 (Table 1). In mixtures, bulk density ranged from 0.33 to $0.58 \mathrm{~g} \mathrm{~cm}^{-3}$. These values according to Pardossi et al. (2011) are within the adequate range for greenhouse and nursery crops $\left(0.19-0.7 \mathrm{~g} \mathrm{~cm}^{-3}\right)$. The addition of MSW compost increases the bulk density of the coir, which may reduce water holding capacity and improve air-, water-relationship. As container height drastically affects air space in a substrate (sponge effect), in the future, it will be important to analyze their influence on the air and water content in the mixtures.

Table 1. Physicochemical characteristics of coir/MSW compost mixtures.

\begin{tabular}{|c|c|c|c|c|c|c|}
\hline & \multicolumn{6}{|c|}{ Coir/MSW compost ratios } \\
\hline$(v / v)^{a}$ & 1:0 & 3:1 & $2: 1$ & $1: 1$ & $1: 2$ & $0: 1$ \\
\hline$(w / w)^{b}$ & 1:0 & 1:1.8 & 1:2.7 & 1:5.4 & 1:10.8 & $0: 1$ \\
\hline$E C_{w}\left(d S m^{-1}\right)$ & $1.66 \mathrm{f}$ & $2.69 \mathrm{e}$ & $2.99 \mathrm{~d}$ & $4.01 \mathrm{c}$ & $4.41 \mathrm{~b}$ & $4.81 \mathrm{a}$ \\
\hline Organic carbon (\%) & $36.14 \mathrm{a}$ & $30.71 b$ & $30.74 b$ & $30.16 b$ & $28.34 \mathrm{c}$ & $24.51 \mathrm{~d}$ \\
\hline Organic matter (\%) & $62.30 \mathrm{a}$ & $52.94 \mathrm{~b}$ & $52.99 \mathrm{~b}$ & $52.00 \mathrm{~b}$ & $48.85 \mathrm{c}$ & $41.7 \mathrm{~d}$ \\
\hline $\mathrm{pH}_{\mathrm{H} 2 \mathrm{O}}$ & $5.62 \mathrm{e}$ & $6.73 d$ & $6.89 \mathrm{c}$ & $6.99 \mathrm{c}$ & $7.16 \mathrm{~b}$ & $8.21 \mathrm{a}$ \\
\hline Mass wetness (g water $\mathrm{g}^{-1}$ substrate) & $7.55 \mathrm{a}$ & $3.72 b$ & $3.51 \mathrm{~b}$ & $2.76 \mathrm{c}$ & $2.70 \mathrm{c}$ & $1.28 d$ \\
\hline Moisture content (\%, W/W) & $88.04 \mathrm{a}$ & $78.36 \mathrm{~b}$ & $77.38 \mathrm{~b}$ & $72.42 \mathrm{c}$ & $72.83 \mathrm{c}$ & $58.08 \mathrm{e}$ \\
\hline Bulk density $\left(\mathrm{g} \mathrm{cm}^{-3}\right)$ & $0.11 \mathrm{f}$ & $0.33 \mathrm{e}$ & $0.40 \mathrm{~d}$ & $0.47 \mathrm{c}$ & $0.58 \mathrm{~b}$ & $0.79 \mathrm{a}$ \\
\hline
\end{tabular}

a, b: Coir/ MSW compost ratio by volume and by weight in mixture, respectively.

Means followed by different letters within a row are significantly different by the $\mathrm{LSD}_{0.05}$ test. Values are means of five replications.

Mass wetness, moisture and organic carbon and organic matter content increase with the increase of coir in mixture. The average levels of organic matter in MSW compost were 41.7\% meaning the MSW compost is thoroughly composted, which contributes to substrate stability. Composts with levels of organic matter higher than $65 \%$ may not have been thoroughly composted (Sullivan et al., 2018). Taking into account the physicochemical characteristics measuring the EC is the one that raises more issues. Therefore, of the mixtures made the most suitable mixture was the one with the coir/MSW compost ratio 3:1 with, but still with a high salinity of $2.69 \mathrm{dS} \mathrm{m}^{-1}$.

The mixture of coir and acacia wood biochar in different ratios affected significantly the physicochemical characteristics measured (Table 2). The EC of biochar alone was low $\left(0.24 \mathrm{dS} \mathrm{m}^{-1}\right)$ and its increase in the mixture decreased the values of electrical conductivity, which ranged from 0.59 to $1.13 \mathrm{dS} \mathrm{m}^{-1}$ (Table 2). These EC values are lower than the salinity threshold of the majority of the crops. On the contrary, biochar used alone as a rooting medium presents a too high $\mathrm{pH}$ (9.11). The addition of coir contributes to decreasing the $\mathrm{pH}$. In the mix 3:1 the $\mathrm{pH}$ decreased to 6.74 , which is slightly above the maximal value of adequate range (6.4) as mentioned previously. Mass wetness, moisture content and bulk density were improved by the addition of coir to the mixture (Table 2). The addition of biochar increases the bulk density of the coir, which may improve the air-water relationship. This can be an advantage since biochar decomposes very slowly relative to other organic amendments, maintaining the initial physical characteristics of the substrates over time (Vaughn et al., 2013).

Taking into account the physical and chemical characteristics measured, in the MSW compost the most limiting characteristics were the high $\mathrm{EC}$ and $\mathrm{pH}$ and in biochar the high $\mathrm{pH}$. The addition of coir improved those characteristics and in either case, the most suitable mixture was the one with the ratio $3: 1$ (75\% coir by volume in the mixture). However, the $\mathrm{EC}_{\mathrm{w}}\left(2.69 \mathrm{dS} \mathrm{m}^{-1}\right)$ of the mix 3:1 coir/MSW compost was still higher than the salinity threshold of the majority of the crops. That can be addressed by increasing the coir in the mixture since in mixture coir/MSW ratio 3:1 represents only $37 \%$ by weight of the mixture (Table 1). Despite the value of the EC, the effects of salt stress in plant growth may be reduced due to the humic acids present in MSW compost, which increase crop salt tolerance (Ouni et al., 2014). This issue also can be reduced by adjustments in crop fertilization, e.g. using reduced-strength nutrient solutions at the beginning of the crop growing cycle and 
considering the MSW compost nutrients content into plant nutrition. The $\mathrm{pH}$ in both growing media (coir/MSW and coir/biochar) at the 3:1 ratio (6.7) was slightly above the maximal value of adequate range (6.4). Therefore, this may not represent a constraint, regardless of the buffer power of the substrate it is necessary to slightly increase the hydronium concentration $\left(\mathrm{H}_{3} \mathrm{O}^{+}\right)$in the growing media. The $\mathrm{pH}$ can adjust by the nutrient solution acidification. The $\mathrm{pH}$ also can be corrected by nitric and phosphoric acid application as a source of $\mathrm{N}$ and $\mathrm{P}$. The use of chelated nutrients to improve plant nutrients uptake also is a possibility. On the other hand, the humic substances present in MSW compost also may contribute to increasing micronutrient availability (Tan, 2014). Therefore, the mix of coir with MSW compost and biochar in proportion 3:1 (v/v) with some adjustments, may have the potential to grow plants. However, further evaluation will be necessary to evaluate the effects of these mixtures on plant growth, nutrient uptake and quality.

Table 2. Physicochemical characteristics of coir/biochar mixtures.

\begin{tabular}{|c|c|c|c|c|c|c|}
\hline & \multicolumn{6}{|c|}{ Coir/biochar ratios } \\
\hline$(v / v)^{a}$ & 1:0 & $3: 1$ & $2: 1$ & 1:1 & $1: 2$ & $0: 1$ \\
\hline$(w / w)^{b}$ & 1:0 & $1: 1.25$ & 1.1 .88 & 1:3:76 & $1: 7.54$ & $0: 1$ \\
\hline $\mathrm{EC}_{\mathrm{w}}\left(\mathrm{dS} \mathrm{m}^{-1}\right)$ & $1.66 \mathrm{a}$ & $1.13 b$ & $1.03 c$ & $0.95 d$ & $0.59 \mathrm{e}$ & $0.24 \mathrm{f}$ \\
\hline Organic carbon (\%) & $36.14 \mathrm{e}$ & $51.71 \mathrm{bcd}$ & $57.84 \mathrm{bc}$ & $60.8 b$ & $66.52 \mathrm{~b}$ & $76.39 a$ \\
\hline $\mathrm{pH}_{\mathrm{H} 2 \mathrm{O}}$ & $5.62 \mathrm{f}$ & $6.74 \mathrm{e}$ & $7.34 \mathrm{~d}$ & $7.85 \mathrm{c}$ & $8.26 \mathrm{~b}$ & $9.11 \mathrm{a}$ \\
\hline Mass wetness ( $\mathrm{g}$ water $\mathrm{g}^{-1}$ substrate) & $7.55 \mathrm{a}$ & $4.67 \mathrm{~b}$ & $4.03 \mathrm{c}$ & $3.04 d$ & $2.25 \mathrm{e}$ & $1.74 \mathrm{f}$ \\
\hline Moisture content $(\%$, W/W $)$ & $88.04 \mathrm{a}$ & $82.35 b$ & $80.14 \mathrm{c}$ & $75.51 d$ & $69.30 \mathrm{e}$ & $63.54 \mathrm{f}$ \\
\hline Bulk density $\left(\mathrm{g} \mathrm{cm}^{-3}\right)$ & $0.10 \mathrm{f}$ & $0.16 \mathrm{e}$ & $0.18 \mathrm{~d}$ & $0.22 \mathrm{c}$ & $0.28 \mathrm{~b}$ & $0.34 \mathrm{a}$ \\
\hline
\end{tabular}

a and b: Coir/biochar ratio by volume and by weight in mixture, respectively.

Means followed by different letters within a row are significantly different. Values are means of five replications.

\section{CONCLUSIONS}

The most limiting characteristics in the MSW compost were the high EC and pH and in biochar the high $\mathrm{pH}$. The increase of coir in mix improved the chemical and physical characteristics and in either case, the most suitable mixture was the one with the ratio 3:1 ( $75 \%$ coir by volume in the mixture). The $\mathrm{pH}$ in mixtures coir/MSW and coir/biochar at the $3: 1$ ratio was slightly above the maximal value of adequate range to substrates, so adjusting the $\mathrm{pH}$ will be easy.

\section{ACKNOWLEDGEMENTS}

This work is funded by National Funds through FCT - Foundation for Science and Technology under the Project UIDB/05183/2020.

\section{Literature cited}

Bailey, D.A., Nelson, P.V., and Fonteno, W.C. (2000). Substrates pH and Water Quality. Raleigh, NC (USA: North Carolina State University).

Brady, N., and Weil, R. (1996). The Nature and Properties of Soils, $12^{\text {th }}$ edn (New Jersey, USA: Prentice), p.385495.

Fascella, G. (2015). Growing substrates alternative to peat for ornamental plants. In Soilless Culture - Use of Substrates for the Production of Quality Horticultural Crops, Md. Asaduzzaman, ed. (InTech Publication), p.4767. https://doi.org/10.5772/59596

Fonteno, W.C., and Harden, C.T. (2003). Procedures for Determining Physical Properties of Horticultural Substrates Using the NCSU Porometer (Horticultural Substrates Laboratory, North Carolina State University). https://www.ncsu.edu/project/hortsublab/pdf/porometer_manual.pdf.

Graber, E.R., Meller Harel, Y., Kolton, M., Cytryn, E., Silber, A., Rav David, D., Tsechansky, L., Borenshtein, M., and Elad, Y. (2010). Biochar impact on development and productivity of pepper and tomato grown in fertigated soilless media. Plant Soil 337 (1-2), 481-496 https://doi.org/10.1007/s11104-010-0544-6. 
Gruda, N.S. (2019). Increasing sustainability of growing media constituents and stand-alone substrates in soilless culture systems. Agronomy (Basel) 9 (6), 298 https://doi.org/10.3390/agronomy9060298.

Gruda, N., Caron, J., Prasad, M., and Maher, M. (2016). Growing media. In Encyclopedia of Soil Science (CRC Press), p.1053-1058. https://doi.org/10.4324/9781315161860.

Hargreaves, J.C., Adl, M.S., and Warman, P.R. (2008). A review of the use of composted municipal solid waste in agriculture. Agric. Ecosyst. Environ. 123 (1-3), 1-14 https://doi.org/10.1016/j.agee.2007.07.004.

Machado, R., and Serralheiro, R. (2017). Soil salinity: effect on vegetable crop growth. management practices to prevent and mitigate soil salinization. Horticulturae 3 (2), 30 https://doi.org/10.3390/horticulturae3020030.

Machado, R., and Serralheiro, R. (2020). Salt stress alleviation through fertilization in fruit crops. In Fruits Crops, A.K. Srivastava, and C. Hu, eds. (Elsevier), p.465-480. https://doi.org/10.1016/B978-0-12-818732-6.00033-2

Michel, J.C. (2010). The physical properties of peat: a key factor for modern growing media. Mires Peat 6, 1-90.

Ouni, Y., Ghnaya, T., Montemurro, F., Abdelly, C., and Lakhdar, A. (2014). The role of humic substances in mitigating the harmful effects of soil salinity and improve plant productivity. Int. J. Agron. Plant Prod. 8 (3), 353-374.

Pardossi, A., Carmassi, G., Diara, C., Incrocci, L., Maggini, R., and Massa, D. (2011). Fertigation and Substrate Management in Closed Soilless Culture. EUPHOROS report (UNIPI).

Pribyl, D.W. (2010). A critical review of the conventional SOC to SOM conversion factor. Geoderma 156 (3-4), 7583 https://doi.org/10.1016/j.geoderma.2010.02.003.

Sohi, S.P., Krull, E., Lopez-Capel, E., and Bol, R. (2010). A review of biochar and its use and function in soil. Adv. Agron. 105, 47-82 https://doi.org/10.1016/S0065-2113(10)05002-9.

Sullivan, D.M., Bary, A.I., Miller, R.O., and Brewer, L.J. (2018). Interpreting Compost Analyses (USA: Oregon State University Extension Service).

Tan, K.H. (2014). Humic Matter in Soil and the Environment: Principles and Controversies (CRC Press). https://doi.org/10.1201/9780203912546

Vaughn, S.F., Kenar, J.A., Thompson, A.R., and Peterson, S.C. (2013). Comparison of biochars derived from wood pellets and pelletized wheat straw as replacements for peat in potting substrates. Ind. Crops Prod. 51, 437-443 https://doi.org/10.1016/j.indcrop.2013.10.010. 
